\title{
Field Evaluation of Genetic Variability of Cotton Gossypium hirsutum L. Genotypes against Sucking Pests and Bollworms
}

\author{
M. Sivarama Krishna* and Y. Rama Reddy \\ Regional Agricultural Research Station, Nandyal 518502; Andhra Pradesh, India \\ *Corresponding author
}

A B S T R A C T

\begin{tabular}{l} 
K e y w o r d s \\
$\begin{array}{l}\text { Genotype, } \\
\text { Tolerance, Sucking } \\
\text { pests, Emerging } \\
\text { pests, Bollworm } \\
\text { complex }\end{array}$ \\
Article Info \\
$\begin{array}{l}\text { Accepted: } \\
\text { 04 October } 2020 \\
\text { Available Online: } \\
\text { 10 November } 2020\end{array}$ \\
\hline
\end{tabular}

\section{Introduction}

Cotton Gossypium hirsutum L. (Family: Malvaceae) is the major commercial crop cultivated in India, majority of the cotton area is occupied with Bollgard II cotton which contains crystal proteins of Cry I AC and Cry II $\mathrm{AB}$ which confers resistance to bollworms $[1,2]$. The Bollgard-I with a single Bt gene was followed in 2006 by Bollgard-II with two $\mathrm{Bt}$ genes. Currently $\mathrm{Bt}$ cotton hybrids expressing six events different combination of three $\mathrm{Bt}$ genes have been commercialized in India. These have been introduced into 780 cotton hybrids. From a low initial uptake in
2002, Bt cotton has spread to over $85 \%$ of the cotton area, covering 9.4 million hectares in 2010-11 [3]. Bt cotton performed satisfactorily during the initial years of release but off late during the last one decade there was wide spread attack of pink bollworm on Bt-II cotton throughout the country making it vulnerable to the pink bollworm. Resistance monitoring studies done at CICR have demonstrated that bollworm Helicoverpa armigera, the target pest of $\mathrm{Bt}$ cotton, has developed tolerance for it. Other studies have also shown bollworm surviving and reproducing in $\mathrm{Bt}$ cotton both single gene and double gene Bt [4]. Though Bt cotton has 
been found successful in the management of bollworms to some extent barring pink bollworm, however, it has invited other insect pests especially sucking pests due to reduction in pesticide sprays at early stage. Resistance to $\mathrm{Bt}$ cotton in pink bollworm is now widespread in India, and resistance to insecticide in many pests is increasing [5]. Before the advent of $\mathrm{Bt}$ cotton in India i.e. prior to 20002 majority of the cotton area was covered with Gossypium hirsutum either with straight varieties of intra hirsutum hybrids which is known as American and upland cotton which produces about $90 \%$ of the total cotton production in the world. insecticide valued at US \$ 660 million are used annually on all crops in India, of which more than half are used on Bt cotton[6]. In India, cotton is grown as a staple cash crop and accounts for 126.07 M hectare area with 337 MT of production during 2018-19. Bt cotton off late is becoming increasingly susceptible to sucking pests particularly leaf hoppers Amrasca devastans Distant and other sucking pests like whiteflies, Thrips, Mealy bug and Mirid bug. Leafhopper alone can cause damage upto the extent of $38-44 \%$ during the period of heavy incidence. The cotton Mirid bug Creontiades biseratense (Distant) found as emerging pests of Bt cotton and found in Tamil nadu, Andhra Pradesh and Maharashtra[7]. Cotton Mirid bug Creontiades biseratense (Distant) causing heavy shredding of squares and bolls which lead to significant reduction in seed cotton yield [8] Monsanto disclosed that the cotton pest pink bollworm Pectinophora gossypiella saunders had developed resistance to the Cry 1Ac toxin (Bt) in Bollgard I in Gujarat [9] the first State where $\mathrm{Bt}$ cotton was planted commercially. Resistance monitoring studies done at CICR have demonstrated that bollworm Helicoverpa armigera the target pest of Bt cotton, has developed tolerance for it. Other studies have also shown bollworm surviving and reproducing in Bt cotton both single gene and double gene $\mathrm{Bt}$ [10]. Emergence of secondary pests In his 2011 report Dr. Kranthi states Productivity in north India is likely to decline because of the declining potential of hybrids, the emerging problem of leaf curl virus on the new susceptible Bt-hybrids a high level of susceptibility to sucking pests (straight varieties were resistant) problems with nutrient deficiencies and physiological disorders and mealy bugs, whiteflies and miscellaneous insect problems that are likely to increase. Grey mildew once a serious problem in diploid cotton especially in central India has now become a major problem in $\mathrm{Bt}$ cotton hybrids in central and south zone in India [11]. Cotton is infested by a large number of insect pests right from the sowing till harvest in the early stages, sucking pests like aphids, thrips, leaf hoppers and white flies cause serious problem and resulting reduction in yield and quality of cotton. The sucking pests cause 22.58 per cent reduction in cotton yield [12]. Mealy bug not observed in India before, has spread in the cotton regions and farmers have been spraying extremely hazardous pesticides to eliminate this hard-to-kill pest.

The prolific spread of Bt cotton hybrids has created a conducive climate for the rapid spread of this pest. Looking at the inconsistent performance of Bt cotton hybrids since last few years under changing scenario of climate, group of farmers particularly cultivating cotton on marginal soils under rain fed conditions are looking forward to non $\mathrm{Bt}$ varieties or hybrids of Gossypium hirsutum, keeping in view of the short comings of boll gard II cotton it is time for refocusing our breeding research on straight hirsutum varieties which are comparatively more tolerant to insect pests than Bt cotton and also yields at par with $\mathrm{Bt}$ cotton under good management practices. Hence the present study was aimed at screening the cotton 
hirsutum genotypes in field condition provided by AICRP- Cotton Coimbatore for their tolerance towards sucking pests and bollworms which in future may be used as parent material in developing an elite variety or non Bt hybrid.

\section{Materials and Methods}

A Field trial was conducted to screen the cotton hirsutum genotypes provided by the AICRP-Cotton, Coimbatore under initial evaluation trial of cotton genotypes at Regional Agricultural Research Station, Nandyal during kharif 2018. A total 27 cotton genotypes were field evaluated for their reaction against sucking pests and boll worms, trial was laid out in Randomized block design with three replications. Standard susceptible check for sucking pests DCH-32 hybrid and tolerant check NDLH-1938 variety were used and tolerant check for bollworms BG-II (Jadoo) and susceptible check DCH-32 were used for comparison of genotypes. Each entry was laid in three meters row length with two rows for each entry with spacing of $60 \times 30 \mathrm{~cm}$ was maintained between the rows and plants respectively, after every three entries a row of bhendi crop was raised as infestor row to build up natural leafhopper population.

All the standard agronomic practices were adopted as prescribed by the university except plant protection measures. Sucking pests count was taken on five tagged plants from each entry on three leaves top, middle and bottom. Data on sucking pests was recorded at 30,60, and 90 DAS, green boll damage by Helicoverpa armigra, Earias vitell and Pectinophora gossypiella were recorded at $100,110,140$ DAS open boll damage and locule damage was recorded at 150 DAS. Yield of seed cotton in $\mathrm{kg} / \mathrm{ha}$ was recorded at the time of harvest the data thus obtained was subjected to statistical analysis.

\section{Results and Discussion}

Under this trial, total of 27 entries along with four checks (B.G II, non Bt, NDLH-1938, DCH-32) were screened for their resistance against insect pests of cotton. Among the 27 entries screened the entry CNH 2052 has recorded the lowest leafhopper population of 2.87 leafhoppers/ 3 leaves which was on par with majority of the entries. However, the highest leafhopper population (8.87 leafhoppers/ 3 leaves) was recorded in Standard susceptible check DCH-32. Jassid population was below ETL in all the entries. The other sucking pests like thrips and whiteflies were also recorded below ETL. No significant difference was observed among the entries with respect to natural enemy population.

Among the bollworms, the field incidence of Helicover armigera, Spodoptera litura and Earias spp was almost negligible. The entry LC has recorded the lowest green boll damage (boll basis) $9.70 \%$ by pink bollworm which was on par with the majority of the entries. Standard tolerant check B.G-II had recorded a damage of $11.13 \%$. However highest green boll damage of $20 \%$ was recorded in entry ADB 645. Standard check BG II had recorded a lowest of $6.11 \%$ open boll damage, which was on par with entries AKH 10-3, CPD 1851, RAH 1075 and RHC 1307 which recorded $8.73,9.65,7.66,9.41 \%$ respectively.

The lowest open boll locule damage of 2.04 $\%$ was recorded in standard check B.G.II which was on par with entries CNH 1131, ADB 645, CNH 16300, CPD 1852, NH 704, BGDS 1077, ZC (NH 615/ NDLH 1938), RAH 1076 which recorded 2.16, 2.22, 2.34, $3.19,3.33,3.56,3.62$ and $3.71 \%$ respectively. Whereas the highest open boll locule damage was recorded in check DCH-32 (7.39 \%). (Table 1 \& 2). 
Table.1 Reaction of cotton hirsutum germplasm against sucking pests

\begin{tabular}{|c|c|c|c|c|c|c|c|}
\hline \multirow[t]{2}{*}{ Entrycode } & \multirow{2}{*}{$\begin{array}{l}\text { Jassid } \\
\text { injury } \\
\text { Grade }\end{array}$} & \multicolumn{2}{|c|}{$\begin{array}{l}\text { Jassids } \\
\text { /3leaves }\end{array}$} & \multicolumn{2}{|c|}{$\begin{array}{l}\text { Whitefly } \\
\text { /3leaves }\end{array}$} & \multicolumn{2}{|c|}{$\begin{array}{l}\text { Thrips/ } \\
\text { 3leaves }\end{array}$} \\
\hline & & $0 . \mathrm{V}$ & T.V & $\mathbf{O . V}$ & T.V & $0 . \mathrm{V}$ & T.V \\
\hline RHC 1306 & I & 3.60 & $2.02 *$ & 0.27 & $0.87^{*}$ & 0.00 & $0.71^{*}$ \\
\hline $\begin{array}{l}\text { ZC (NH 615/ NDLH } \\
1938)\end{array}$ & II & 4.20 & 2.15 & 0.13 & 0.79 & 0.00 & 0.71 \\
\hline RAH 1076 & II & 4.20 & 2.13 & 0.27 & 0.87 & 0.33 & 0.88 \\
\hline AKH 10-3 & I & 3.07 & 1.88 & 0.13 & 0.79 & 0.93 & 1.14 \\
\hline CPD 1852 & I & 3.67 & 2.04 & 0.00 & 0.71 & 0.27 & 0.85 \\
\hline ADB 645 & I & 3.93 & 2.10 & 0.00 & 0.71 & 0.00 & 0.71 \\
\hline NDLH - 2057-1 & I & 3.20 & 1.92 & 0.07 & 0.75 & 0.73 & 1.02 \\
\hline NH 704 & I & 3.93 & 2.10 & 0.13 & 0.79 & 0.40 & 0.91 \\
\hline CNH 2052 & I & 2.87 & 1.83 & 0.27 & 0.87 & 0.00 & 0.71 \\
\hline LC & II & 4.27 & 2.17 & 0.00 & 0.71 & 0.00 & 0.71 \\
\hline CNH 09/11 & II & 3.87 & 2.08 & 0.13 & 0.79 & 0.27 & 0.85 \\
\hline CNH 2073 & II & 3.73 & 2.03 & 0.40 & 0.95 & 0.27 & 0.85 \\
\hline ARBH 1851 & I & 3.27 & 1.94 & 0.20 & 0.84 & 0.40 & 0.93 \\
\hline BS 5-18 & II & 4.13 & 2.14 & 0.20 & 0.83 & 0.20 & 0.82 \\
\hline GBHV 200 & II & 4.33 & 2.19 & 0.20 & 0.84 & 0.33 & 0.88 \\
\hline CPD 1851 & II & 3.87 & 2.09 & 0.07 & 0.75 & 0.20 & 0.82 \\
\hline CNH 1131 & I & 3.80 & 2.06 & 0.33 & 0.91 & 0.87 & 1.12 \\
\hline NDLH - 2035-5 & I & 3.53 & 1.99 & 0.33 & 0.90 & 0.60 & 1.02 \\
\hline BGDS 1077 & II & 4.60 & 2.26 & 0.27 & 0.87 & 0.40 & 0.93 \\
\hline BS 6-18 & I & 3.27 & 1.93 & 0.27 & 0.85 & 0.33 & 0.88 \\
\hline CNH 16300 & II & 4.13 & 2.13 & 0.13 & 0.79 & 0.73 & 1.06 \\
\hline CNH 09-73 & I & 3.40 & 1.95 & 0.20 & 0.83 & 0.07 & 0.75 \\
\hline RHC 1307 & I & 3.67 & 2.03 & 0.00 & 0.71 & 0.87 & 1.13 \\
\hline RAH 1075 & II & 4.60 & 2.25 & 0.13 & 0.79 & 0.40 & 0.93 \\
\hline GBHV 201 & I & 4.00 & 2.09 & 0.13 & 0.79 & 0.40 & 0.91 \\
\hline Quality Check (Suraj) & I & 4.60 & 2.25 & 0.13 & 0.79 & 1.33 & 1.29 \\
\hline H 1525 & I & 3.00 & 1.87 & 0.27 & 0.87 & 0.40 & 0.93 \\
\hline BG-II & I & 3.80 & 2.03 & 0.20 & 0.83 & 0.73 & 1.06 \\
\hline DCH-32 & III & 8.87 & 3.05 & 0.13 & 0.79 & 0.00 & 0.71 \\
\hline NDLH-1938 & II & 5.27 & 2.40 & 0.13 & 0.79 & 0.00 & 0.71 \\
\hline Non-bt & I & 3.33 & 1.95 & 0.13 & 0.79 & 0.33 & 0.88 \\
\hline F-Test & & $\mathbf{S}$ & & NS & & NS & \\
\hline SEd & & 0.22 & & 0.09 & & 0.23 & \\
\hline $\mathrm{CD}(\mathrm{P}=\mathbf{0 . 0 5})$ & & 0.45 & & NS & & NS & \\
\hline $\mathrm{CV}(\%)$ & & 13.08 & & 13.78 & & 31.28 & \\
\hline
\end{tabular}

TV are $\sqrt{(x+0.5)}$ transformed values

** TV are arc-sin transformed values 
Table. 2 Reaction of cotton hirsutum germplasm against bollworm complex

\begin{tabular}{|c|c|c|c|c|c|c|c|c|c|}
\hline \multirow[t]{3}{*}{ Entry code } & \multirow{2}{*}{\multicolumn{2}{|c|}{$\begin{array}{c}\text { Natural } \\
\text { Enemies/plant }\end{array}$}} & \multicolumn{6}{|c|}{ Percentage of boll damage } & \multirow{3}{*}{$\begin{array}{c}\text { yield } \\
\text { (kg/ha) }\end{array}$} \\
\hline & & & \multicolumn{2}{|c|}{$\begin{array}{c}\text { Green boll } \\
\text { damage }(\%)\end{array}$} & \multicolumn{2}{|c|}{$\begin{array}{c}\text { Open boll } \\
\text { damage }(\%)\end{array}$} & \multicolumn{2}{|c|}{$\begin{array}{c}\text { Locule } \\
\text { damage }(\%)\end{array}$} & \\
\hline & $\mathrm{O} . \mathrm{V}$ & T.V & O.V & T.V & $\mathrm{O} . \mathrm{V}$ & T.V & O.V & T.V & \\
\hline RHC 1306 & 0.00 & $0.71 *$ & 14.11 & $21.99 * *$ & 13.36 & $21.36 * *$ & 4.04 & $11.49 * *$ & 581 \\
\hline $\begin{array}{l}\text { ZC (NH 615/ } \\
\text { NDLH 1938) }\end{array}$ & 0.20 & 0.83 & 10.90 & 19.24 & 11.67 & 19.87 & 3.62 & 10.89 & 946 \\
\hline RAH 1076 & 0.07 & 0.75 & 12.00 & 20.10 & 12.05 & 20.19 & 3.71 & 11.09 & 579 \\
\hline AKH 10-3 & 0.13 & 0.79 & 13.35 & 21.39 & 8.73 & 17.13 & 4.47 & 12.14 & 820 \\
\hline CPD 1852 & 0.07 & 0.75 & 10.27 & 18.62 & 17.18 & 24.43 & 3.19 & 10.27 & 902 \\
\hline ADB 645 & 0.00 & 0.71 & 20.00 & 26.46 & 18.19 & 24.99 & 2.22 & 8.37 & 1067 \\
\hline NDLH -2057-1 & 0.00 & 0.71 & 11.33 & 19.49 & 13.66 & 21.60 & 6.45 & 14.62 & 859 \\
\hline NH 704 & 0.07 & 0.75 & 10.68 & 19.01 & 11.78 & 20.07 & 3.33 & 10.48 & 807 \\
\hline CNH 2052 & 0.00 & 0.71 & 19.85 & 26.31 & 20.13 & 26.63 & 6.27 & 14.40 & 1286 \\
\hline LC & 0.07 & 0.75 & 9.70 & 18.09 & 12.63 & 20.78 & 5.08 & 13.00 & 873 \\
\hline CNH 09/11 & 0.13 & 0.79 & 16.44 & 23.87 & 12.37 & 20.57 & 4.75 & 12.47 & 531 \\
\hline CNH 2073 & 0.07 & 0.75 & 10.07 & 18.49 & 22.52 & 28.21 & 4.79 & 12.47 & 954 \\
\hline ARBH 1851 & 0.13 & 0.79 & 10.18 & 18.55 & 13.72 & 21.62 & 5.16 & 13.11 & 1584 \\
\hline BS 5-18 & 0.07 & 0.75 & 10.59 & 18.93 & 18.74 & 25.55 & 3.95 & 11.25 & 1438 \\
\hline GBHV 200 & 0.07 & 0.75 & 14.86 & 22.57 & 17.90 & 24.92 & 5.14 & 13.10 & 886 \\
\hline CPD 1851 & 0.00 & 0.71 & 17.25 & 24.28 & 9.65 & 17.99 & 6.00 & 14.11 & 953 \\
\hline CNH 1131 & 0.13 & 0.79 & 13.47 & 21.50 & 14.04 & 21.93 & 2.16 & 8.22 & 1056 \\
\hline NDLH -2035-5 & 0.00 & 0.71 & 12.33 & 20.51 & 13.59 & 21.61 & 5.25 & 13.09 & 1414 \\
\hline BGDS 1077 & 0.00 & 0.71 & 9.73 & 17.92 & 16.46 & 23.84 & 3.56 & 10.85 & 864 \\
\hline BS 6-18 & 0.07 & 0.75 & 17.07 & 24.30 & 15.19 & 22.89 & 6.55 & 14.68 & 1771 \\
\hline CNH 16300 & 0.07 & 0.75 & 10.94 & 19.26 & 15.59 & 23.25 & 2.34 & 8.80 & 937 \\
\hline CNH 09-73 & 0.07 & 0.75 & 16.22 & 23.65 & 13.49 & 21.44 & 5.42 & 13.35 & 800 \\
\hline RHC 1307 & 0.00 & 0.71 & 14.67 & 22.49 & 9.41 & 17.69 & 3.75 & 11.15 & 2070 \\
\hline RAH 1075 & 0.00 & 0.71 & 13.40 & 21.42 & 7.66 & 16.04 & 2.79 & 9.57 & 1827 \\
\hline GBHV 201 & 0.00 & 0.71 & 10.74 & 19.10 & 10.84 & 19.02 & 2.06 & 8.21 & 1274 \\
\hline $\begin{array}{l}\text { Quality Check } \\
\text { (Suraj) }\end{array}$ & 0.00 & 0.71 & 17.75 & 24.67 & 16.13 & 23.62 & 4.06 & 11.57 & 1427 \\
\hline H 1525 & 0.00 & 0.71 & 10.37 & 18.73 & 13.15 & 21.24 & 4.68 & 12.34 & 799 \\
\hline BG-11 & 0.00 & 0.71 & 11.13 & 19.45 & 6.11 & 14.29 & 2.04 & 8.16 & 1202 \\
\hline DCH-32 & 0.13 & 0.79 & 12.61 & 20.79 & 28.61 & 32.28 & 7.39 & 15.65 & 755 \\
\hline NDLH-1938 & 0.07 & 0.75 & 12.17 & 20.25 & 12.47 & 20.66 & 7.31 & 15.56 & 1227 \\
\hline Non-bt & 0.00 & 0.71 & 11.52 & 19.81 & 20.82 & 27.16 & 4.78 & 12.51 & 1194 \\
\hline F-Test & NS & & $\mathrm{S}$ & & $\mathrm{S}$ & & $\mathrm{S}$ & & $\mathrm{S}$ \\
\hline SEd & 0.06 & & 2.25 & & 2.21 & & 1.51 & & 367.73 \\
\hline $\mathrm{CD}(\mathrm{P}=0.05)$ & $\mathrm{NS}$ & & 4.50 & & 4.42 & & 3.02 & & 735.07 \\
\hline CV(\%) & 9.40 & & 13.12 & & 12.24 & & 15.66 & & 41.60 \\
\hline
\end{tabular}


The above results indicate that some of the cotton hirsutum genotypes have the innate potential of tolerance towards sucking pests and bollworms and can be further exploited as parent material in future breeding programmes, the same was corroborated by Percival and Kohel 1990 [13] who studied extensive genetic variation among the members of genus Gossypium. The wild and cultivated species have wider adoptability and high degree of resistance to biotic and abiotic stresses, wild species have been utilized to transfer the resistance to various insect pest and diseases and improving cultivated cotton species especially Gossypium hirsutum [14] new germplasm if used in crop improvement programs can raise the ceiling of genetic yield potential, improve resistance to biotic and abiotic stresses, and add new developmental pathways and ecological adaptations[15] Some of the intra hirsutum cotton hybrids or straight varieties released by different state agricultural universities before the dawn of Bt cotton stands as testimony for potential of hirsutum genotypes they also ruled the cotton cultivation during pre Bt era. NHH 250 an intra hirsutum hybrid developed by cotton research station, Nanded [16] this hybrid is tolerant to Bacterial blight and Alternaria leafspot and also tolerant for sucking pests. NHH -44 [17] released by same station is having rejuvenation quality of flowering also drought tolerant, this hybrid dominated cotton cultivation scenario of the country for two decades and slowly moved out of chain with the introduction of $\mathrm{Bt}$ cotton. Productivity of $\mathrm{Bt}$ cotton in north India is likely to decline because of the declining potential of hybrids and the emerging problem of leaf curl virus on the new susceptible Bt-hybrids, high level of susceptibility to sucking pests (straight varieties were resistant) problems with nutrient deficiencies and physiological disorders and mealy bugs, whiteflies and miscellaneous insect problems that are likely to increase in Bt cotton. The variety NH-635 released by cotton research station Nanded [18] is found suitable for High density planting systems particularly in shallow soils. The different cotton genotypes have varying densities of trichomes on the leaves absence of trichomes increased the attractiveness of the cotton plant to some major insect pests, thus increasing the reliance on pesticides [19]. The glory of these non $\mathrm{Bt}$ varieties or Hybrids may come back in the coming years as the conversion programme of the straight varieties /Hybrids under public/private partnership. Keeping this in background selection and screening of elite cotton genotypes tolerant to biotic and abiotic stress plays a pivotal role in future breeding programmes.

In conclusion as $\mathrm{Bt}$ cotton hybrids are increasingly becoming vulnerable to different emerging pests, new diseases, and physiological disorders and the yield levels are also becoming plateau, it is high time for breeders to evolve and screen new cotton germplasm which are tolerant to biotic and abiotic stress and which are high yielders which will become parent material for future breeding programmes. The selection of the best cotton varieties to be grown at farms level requires a detail comparison of germplasms in local tests that can match with growing conditions of a region. Thus, host plant resistance may be useful as a selection criterion in breeding programs with the objective of improving pests tolerance and yield in cotton which can help to escape the heavy attack occurring throughout the season.

\section{References}

1. Greenplate, J. T., S. R. Penn, Z. Shappley, M. Oppenhuizen, J. Mann, B. Reich, and J. Osborn. 2000. Bollgard II efficacy: quantification of lepidopteran activity in a 2-gene product, pp. 1041Đ1043. In P. Dugger and D. Richter [eds.], Proceedings, 2000 Beltwide Cotton Conference National Cotton Council, Memphis, TN.

2. Stewart, S. D., and K. S. Knighten. 2000. Efficacy of $\mathrm{Bt}$ cotton expressing two insecticidal proteins of Bacillus thuringiensis Berliner on selected caterpillar pests, pp. 1043Đ 1048. In P. Dugger and D. Richter [eds.], Proc. 2000 Beltwide Cotton Conf. National Cotton Council, Memphis, 
TN.

3. Jishnu.L (2011). The cotton saga unravels. http://www.downtoearth.org.in/content/cott on-saga-unravels

4. Ranjith M.T, Prabhuraj A. and Srinivasa B.. (2010). Survival and reproduction of natural populations of Helicoverpa armigera on Btcotton hybrids in Raichur, India. Current Science, 99, (11) 1602-1606. Retrieved September 4, 2011,

5. http://www.ias.ac.in/currsci/10dec2010/160 2

6. Kranthi. K (2011). Part-3: 10 years of Bt in India. http://www.cotton247.com/ news/ci/storyid=2171

7. Kranthi K. R. Cotton production systemsneed for a change in India. Cotton Statistics \& News. 2014;38(16 December 2014):4-7.

8. Hosagudur,G.N Chattanvar, S.N and Kulakarni, Shrikanth, 2008 Screening of Bt cotton and non Bt cotton genotypes for foliar disease. Karnataka journal of Agricultural Sciences 21: 141-143

9. Patil, B.V Bheemana,M, Patil, S.B, Udikeri,S.S, and Hosamani,A, 2006 Record of Mirid bug Creontiodes biseratense(Distant) on cotton from Karnataka, India, Insect Environment, 11, 176-77

10. Surulivelu, T. and Dhara Jothi, B. 2007, http://www.Cicr.gov.in.

11. Sarma, N. and Senguttuvan, N, 2011 Survival of pink bollworm Pectinophora gossypiella (Saunders) on Bt cotton and non Bt cotton in normal and late sowing with a special emphasis to avoid population pressure-World cotton research conference5 7-11 November 2011 pp86

12. Ranjith M.T, Prabhuraj A. and Srinivasa B.
(2010). Survival and reproduction of natural populations of Helicoverpa armigera on Btcotton hybrids in Raichur, India. Current Science, 99, (11) 1602-1606. Retrieved September 4, 2011, from http://www.ias.ac.in/currsci/10dec2010/160 2

13. Percival E and Kohel RJ 1990, Distribution, Collection, and evaluation of Gossypium. Advanced in Agron 44: 225-228,

14. Saptute, U. S., Patil, V. N., Katole, S. R., Men, V. B., Bhagwat, V. R and Thakare, A. V. 1990. Avoidable field losses due to sucking pests bollworm in cotton. Cotton. J. Appl. Zool. Res.1: 67-78

15. Mehetre S.S, Gawande, V.L, and Aher, A.R. Use of exogenous chemicals for overcoming cross incompatibility in Gossypium species. Journal of plant biology. 29: 33-38

16. Kannenberg LW and DE Falk (1995) Models for activation of plant genetic resources for crop breeding programs. Can. J Plant Sci. 75: 45-53.

17. Anonymous. 2015. Release proposal of intra hirsutum cotton hybrid NHH-250 pp. $1-40$

18. Anonymous. 2015. Release proposal of intra hirsutum cotton hybrid NHH-44 for Marathwada region pp. 1-15

19. Anonymous. 2015. Release proposal of intra hirsutum cotton hybrid NHH-635 for Maharastraha state pp. 1-25

20. Nawab NN, Khan IA, Khan AA, Amjad M (2011). Characterization and Inheritance of Cotton Leaf Pubescence. Pak. J. Bot., 43 (1): 649-658.

\section{How to cite this article:}

Sivarama Krishna, M. and Rama Reddy, Y. 2020. Field Evaluation of Genetic Variability of Cotton Gossypium hirsutum L. Genotypes against Sucking Pests and Bollworms. Int.J.Curr.Microbiol.App.Sci. 9(11): 413-419. doi: https://doi.org/10.20546/ijcmas.2020.911.050 